\title{
Determinants of Interior Tourism Industry in kingdom of Saudi Arabia: Economic and Social Impacts
}

\author{
Abeer Abdalla Els aid Kinawy ${ }^{1,2}$, Hafsa Abdelaty Ali Morci ${ }^{1,2^{*}}$ and Raga Mohamed Elzaki ${ }^{1,3}$ \\ ${ }^{1}$ Department of Agribusiness and Consumer Science, College of Agriculture and Food Science, \\ King Faisal University, AlAhsa, Hofuf, Saudi Arabia, 31982. \\ ${ }^{2}$ Agriculture Faculty, Ain Shams University, Egypt. \\ ${ }^{3}$ Department of Rural Economics and Development, Faculty of Animal Production, University of \\ Gezira, Sudan \\ * Corresponding author, telephone: +966569578828, e-mail: akinawy@kfu.edu.sa,
}

Received on: 26-6-2021

Accepted on: 2-9-2021

\begin{abstract}
Given the significance of development of touris msector in KSA, this research aims to identify and address the means that would promote and stimulate domestic tourism in KSA. The study aims to detect the social and economic determinants of the domestic tourism weighting on the foreign tourism, which will being considering in the formulating policies. The results reveal that increase the chances of internal tourism weighting on foreign touris $m$ to the Saudi citizen in compared with non-Saudi resident. The mouthy capita, spending on domestic tourist trip, education, and the effectiveness of the role of the media is one of the most important factors that had increase d the ratio of the weight of internal tourismopportunities in the Kingdom. The study recommends to increase and improve the quality of tourist services and give more attention of internal tourismfor marketing and other purposes as well as the stimulation of local tours.
\end{abstract}

KEYWORDS: domestic tourism, socio-economics characters, internal tourism expenditures.

\section{INTRODUCTION}

Saudi Arabia tourism business occupies a special sector, where it witnessed rapid growth rates in comparison to other sectors. The total contribution of tourism sector in Saudi economic performance is approximately 241 billion Saudi Riyals (RS) in 2017 and increased of approximately $4.6 \%$ of the total GDP growth which is about 5239.13 billion Saudi Riyals (RS) (The world travel and Tourism Council, 2018) and this percentage is expected to reach about $9.4 \%$ of GDP by 2030 Kingdom vision (2017), which stressed the need to neutralize the oil as a source of income through multiple alternative income means that the decisions of huge projects in the tourism sector such as draft right and the Red Sea and recreational camels club and falcons club pour into this direction. Furthermore, the vision presented for localization of entertainment and a way to promote attractions in the Kingdom. Accordingly, the expected entertainment projects have been created thorough studies in terms of responding to the requirements of promoting local tourism, reduce the drain of funds and people abroad in most seasons leading to, and rotate tens of billions inside the home economy instead of wastage on foreign tourism. The UNWTO (2018) also announced that during 2005 and 2016 in
Asia international tourists arrivals increasing an average $7 \%$ per year compared to the world average of $4 \%$. Saudi Arabia accounts for about $80 \%$ of them. Meanwhile the Tourism is one of the wildest growing business of various countries and in 2017 tourists estimated as 1.32 billion arrivals worldwide, that is more with 84 million in compared by 2016 (UNWTO, 2018) KSA has countless prospective for tourism expansions and promotions due to its wellknown ancient religious stories and history, traditional norms and variety of natural ecosystem and well-organized kingdom. In addition, to the KSA try to stimulate and motivate the national income growth. The present study aims to address the indicators of tourism in KSA in terms of tourism preference, purposes, and quality. Furthermore, the study aims to detect the social and economic determinants of the likelihood of domestic tourism weighting on the foreign tourism, which will be being considering in the formulating policies.

From figure 1. The total expenditure of the external tourism beyond 2009 is exceed to the total expenditure of the domestic tourism; however, it is reduced after 2009. The expenditure of the internal tourism is greater than the external tourism during last year's i.e. as the per capita. 


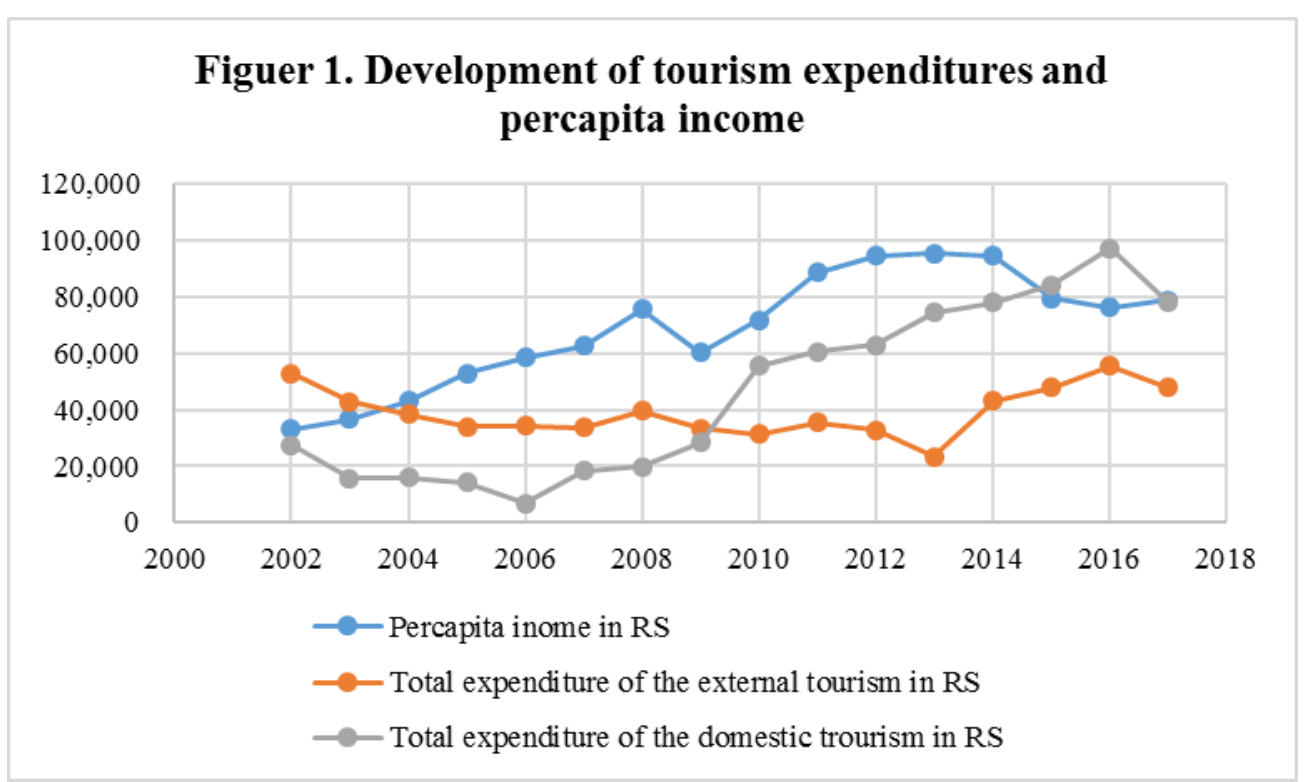

Source: Saudi Arabian Monetary Authority, 2019.

\subsection{Significant of tourism}

In the recent years, definite countries worldwide seek for increasing and variation in the economics earning and put the priority to tourism sector by enriching systematic scientific researches via original articles and /or conferences. Such as the tourism sector act as significant parts for many nations as a source of income, employment, export earnings, public returns and commerce opportunities (Kesar and Čuić, 2017) and represent a dominant role in the economic well-being of some countries particularly the small counties (Šergo and Gržinić, 2018). Recently, tourism being unique of the chief dynamics industries in most countries (Pascariu et al., 2018) and impacts the livelihoods of destination communities for both good and bad moral (Ming et al., 2019) . Whereas, Castañeda et al. (2019) adopting a NOVA method to determine the tourism segments to a destination and spending, and indicate that, there were significant differences in average spend by tourist segment and distribution of total expenditure across the segments. Hence, some tourist travel in groups and the group with which the tourist is travelling affects the individual's spending patterns (Long-Yi \& Chen, 2009). Moreover, Puah et al. (2018) analysing the tourism determinants by achieving the Auto Regressive Distributed Lag (ARDL) test of co-integration to examine the dynamic association between tourism demand and its determinants. In addition, Puah et al., (2014) found that, there are negative association between tourism demand with both exchange rate and travelling costs whereas there the real income and trade openness had positively affect tourism demand. Study achieved by Albaladejo and González-Martínez (2018), using, the nonlinear dynamic econometric model and further advanced to form the standard dynamic equation in order to estimate the tourism demand and effects between previous tourists and quality of tourism services and congestion. They found a non-constant effect of the previous number of tourists over current tourists according to their analysis period. Moreover, both the local tourism industry and related industry and sectors such as agriculture, forestry and fisheries, business associations, administrative agencies, and non-profit organizations should be more openminded tow ard foreigners, so as to promote long stays and cooperate with tourism marketing.

\subsection{Factors affecting tourism}

Many studies search for most factors/ determinants affecting the tourism in the world thus most researches considering the economic, social, habits, geographical and heaths status of the country tourism elements. Furthermore, Manomaivibool (2015) and Filimonau and De Coteau (2019) argued that in developed countries the development and growth of tourism activities in the area correlates positively with hospitality food waste. Nikjoo \& Ketabi, (2015) using pull and push model confirm that motivation is a basic determinant of tourists' behaviour and has an important role in tourism. Yang et al. (2010) confirmed a positive relationship between having heritage sites and tourist numbers in China and the relationship is stronger for natural rather than for cultural heritage sites.

Cafiso et al. (2016) using the gravity model to analyse the tourism economics as trade and they found that there are relationship between distance and travel costs and hence the distance is commonly expected to have a negative effect, in combined on the size of tourism movements. Cheng-Fei and King (2019) state that the top three factors supposed most important to destination attractiveness for tourists 


\section{Abeer Abdalla Elsaid Kinawy et al., 2021}

are provision of accommodation, availability of public transportation and accessibility to tourism attractions. Moreover, Madaleno et al., (2019) mentioned that the traits of local agro-food products, food-related personality characters, as the most important aspects that impact visitors' intentions to consume these products and to recommend them after a tour. Study done by Chen \& Lin (2019) for determining the effect of the weather and macroeconomic conditions on the Taiwan's whalew atching tourism industry and their results indicated that, the main factors effect whale-watching tourisms are temperature and relative price changes. Further Lee and change (2016) adopted some macroeconomics factors to detect the interactions with foreign-exchange earnings from tourism by applying the logistic growth curve and they attained to fact that the logistics growth curve has high explanatory power and that macroeconomic have significant effects on foreign-exchange earnings from tourists.

\section{MATERIAL AND METHODS}

The present study based on the comprehensive primary data using the interview via structural questionnaires. The study adopted sectional data, which gathered through filed survey (2017/2018), whereas the random sample including the regions among the best received by tourists in KSA. Three dissimilar regions in Saudi Arabia named as Medina, Riyadh and Eastern region (Tourist Information and Research Centre, 2018), so as one of the most important shrines of Medina in Saudi Arabia, Riyadh for being the capital city and its urbanization, the eastern region is the largest population areas and by province, Mont-newly designated World Heritage list according to UNESCO.

The study relied on quantitative statistical analysis method by applying logistic regression model to identify the most important factors influencing the likelihood of domestic tourism in the Kingdom on foreign tourism. This model was selected since the dependent variable values are binary variables (preference for domestic tourism or foreign tourism) (Gerdoci, 2017). Logistic regression model was estimated by maximum likelihood method to overcome the problems that arise if the estimate using simple regression method of Ordinary Least Square (OLS). As well as the study using a dummy variable to distinguish the effectiveness or ineffectiveness of the role of information and tourism and antiquities.
According to equation constructed by Puri $(1980)^{1}$ to determine the sample size, given that the total population of Saudi Arabia in 2017 is approximately constituted 32,552,336 inhabitants (General Statically Authority, 2018), the sample size of this study as about 400 people and consequently were grouped around 440 identification, 44 were excluded as identification for not fulfilling the required data where the number of final questionnaires and the analysis about 396 identification only. According to the data identifying the main study variables that are trying to include logistical model according to Kleinbaum and Klein (2010), he stated that the logistic regression is a popular mathematical modelling procedure used in the analysis of epidemiologic data. Whereas the independent variables future included both quantitative and qualitative variables. The information about economics aspects such as the average of per capita income (in $1000 \mathrm{SR} /$ month), average of spending on domestic tourist trip (in 1000 $\mathrm{RS} /$ flight) and other economics quantitative information were gathered. Whereas the qualitative data are collected subject to:

Ordinary variables: Citizen, education level, place the individual's residence, the purpose of internal tourism trip (religious, medical, visit relatives, education..etc.), effectiveness of public authority for tourism campaigns and national heritage, the effectiveness of the role of the media in the promotion of domestic tourism, age, gender, types of transportation using in the internal tourist trip and information about tourism quality.

\section{RESULTS}

Based on study objectives, three qualitative indicators of the tourism had analysed named as tourism preferences, purposes and quality. The simple analysis result illustrates that $68.7 \%$ of the responses prefer foreign tourism while $31.3 \%$ of them prefer domestic tourism (Table 1). In the past Saudi tourists travel to outside nations, particularly to Asian or Europe nations for spending their main vacations but our results indicate that this norm declines and may be related to the financial crisis or improvements/promotions of the domestic tourism in KSA.

${ }^{1}$ Pur equation to determine the sample size illus trates as: $n=\frac{4 N}{4+\frac{(N-1) g^{2}}{p q}}$. Whereas: $n=$ sample size, $\mathrm{N}=$ population size, e: error rate is equal to 0.05 , $\mathrm{p}$ availability of neutral and property equal to $0.50, \mathrm{q}$ : is equal to 0.50 to avoid bias. 
Table 1. Qualitative indicators of tourism in KSA

\begin{tabular}{lll}
\hline Tourism preferences & & $\%$ \\
\hline Tourism manner & Frequencies & 68.7 \\
\hline Internal & 272 & 31.3 \\
External & 124 & 100 \\
Total & 396 & $\%$ \\
\hline Tourism purposes & & 62.12 \\
\hline Tourism purposes & Frequencies & 28.03 \\
\hline Religious tourism & 246 & 8.33 \\
Historicaltourism & 111 & 1.52 \\
(Archaeological) & 33 & \\
leisure tourism & 6 & $\%$ \\
Other & 396 & $28.3 \%$ \\
Total & & $23.9 \%$ \\
\hline Tourism quality & Frequencies & $20.5 \%$ \\
Quality Scales & 112 & $18.5 \%$ \\
\hline Amazing & 95 & $8.8 \%$ \\
Good & 81 & 100 \\
Mediocre & 73 & \\
Need improvement & 35 & \\
Depraved & 396 & \\
Total & & \\
\hline Soure: Feld surey & & \\
\hline
\end{tabular}

Source: Field survey results, 2017/2018.

Furthermore, it is clear that $62.12 \%$ of the samples surveyed prefer religious tourism and $28.03 \%$ of them prefer archaeological tourism while $8.33 \%$ prefer leisure tourism (table 1.). The results of the study reveal that the highest percentages of the sample surveyed ( $28.3 \%$ ) graded domestic tourism in Saudi Arabia as excellent, whereas $23.9 \%, 20.5 \%$ and $18.5 \%$ graded the domestic tourism as good, mediocre and needs to improve; respectively. A few percentages of the sample surveyed $(8.8 \%)$ considered that domestic tourism in Saudi Arabia is depraved.

From table 2, the present results correlation matrix show that, identity card had significant association between internal tourism purposes ( $p$ $>0.05)$ and internal tourism expenditures. $(p>0.01)$, likewise, effectiveness of media reveals a positive relation between effectiveness of public authority for tourism campaigns and internal tourism expenditures ( $p>0.05)$, beside, the latter two variables connected firmly with each other and have highly significant impact on tourism.

Several attempts had performed to estimate a logistic model using SPSS software and exclude variables that did not prove confidence or not consistent with economic logic orientation, whereas the best results are shown in the following table 3 .

From table 3 . It is clear that the designed model seems significantly of the all involved variables in the model according to result of chisquare test. The independent variables included in the model contribute to the likelihood of internal tourism opportunities in the Kingdom on foreign tourism by more of $32 \%$. According to estimated model, is illustrated most important factors among those factors in the study-which increase the ratio of weighted odds ratio of domestic tourism in KSA, the probability that $\mathrm{Y}=1$ ), those factor are included: monthly per capita income, expenditure on internal tourism trip, identity card, purpose of trip, the effectiveness of the role of the media and tourism campaigns effectiveness and effectiveness of the Agency's tourism campaigns. Where there is a direct correlation between the average monthly per capita income and percentage of the weight of domestic tourism in the KSA, so that in case of increase in per capita real 1000/month that will increase the chance of tipping the domestic tourism in Saudi Arabia for foreign tourism by $1 \%$.

Whereas, the results show an inverse relationship between the amount of expenditure on internal tourism trip and the percentage of the weight of domestic tourism in Saudi Arabia for foreign tourism. Hence, that in case of increasing spending on domestic tourist trip by 1000/month, this leads to lower the weight of domestic tourism in the KSA of foreign tourism by about 9\%. Likewise, it is clear that the weight of domestic tourism in Saudi Arabia about the resident foreign tourism below Saudi citizen counterparts by about $48 \%$, this mean that any citizen has increased chances of internal tourism, foreign tourism weighting in comparison to the resident. In case of the purpose of tourism journey in KSA, the results reveal that the ratio of the weight of domestic tourism in Saudi Arabia for foreign tourism for religious purpose it is greater 
Table 2. Simple matrix correlation of the estimated tourism variables

\begin{tabular}{|c|c|c|c|c|c|c|}
\hline Measured variables & PCI & ID & ITP & EM & EPATC & $\overline{\text { ITE }}$ \\
\hline \multicolumn{7}{|l|}{ PCI } \\
\hline \multicolumn{7}{|c|}{$\begin{array}{l}\text { Pearson correlation (Sig. 2- } 1 \\
\text { talied) }\end{array}$} \\
\hline \multicolumn{7}{|c|}{ ID } \\
\hline Pearson Correlation & -0.094 & 1 & & & & \\
\hline Sig. (2-tailed) & $(0.189)$ & & & & & \\
\hline \multicolumn{7}{|l|}{ ITP } \\
\hline Pearson Correlation & 0.051 & $-.258-^{* *}$ & 1 & & & \\
\hline Sig. (2-tailed) & $(0.473)$ & $(0.000)$ & & & & \\
\hline \multicolumn{7}{|l|}{ EM } \\
\hline Pearson Correlation & 0.000 & 0.880 & 0.056 & 1 & & \\
\hline Sig. (2-tailed) & $(1.00)$ & $(.218)$ & $(0.434)$ & & & \\
\hline EPATC & -0.035 & & & & & \\
\hline $\begin{array}{l}\text { Pearson Correlation } \\
\text { Sig. (2-tailed) }\end{array}$ & $(0.626)$ & $\begin{array}{l}-.060- \\
(.399)\end{array}$ & $\begin{array}{l}0.076 \\
(0.287)\end{array}$ & $\begin{array}{l}.410^{* *} \\
(0.000)\end{array}$ & 1 & \\
\hline ITE & & & & & & 1 \\
\hline Pearson Correlation & 0.107 & $-.176^{*}$ & 0.656 & $0.399 * *$ & $0.243 * *$ & \\
\hline Sig. (2-tailed) & $(0137)$ & $(0.013)$ & $(0.656)$ & $(0.000)$ & $(.001)$ & \\
\hline
\end{tabular}

Source: Filed surveyed results, 2017/2018.

**. Correlation is significant at the 0.01 level (2-tailed). *. Correlation is significant at the 0.05 level (2tailed).

Note: $\mathrm{PCI}=$ Per capita income, $\mathrm{ID}=$ Identity card (ID), ITP= Internal tourism purposes, EM= Effectiveness of media, EPATC $=$ Effectiveness of public authority for tourism campaigns, ITE = Internal tourism expenditures.

Table 3. Explanation of logistic regression model for domestic tourism preference in Saudi Arabia

\begin{tabular}{|c|c|c|c|c|c|}
\hline $\begin{array}{l}\text { Variables in the } \\
\text { Equation }\end{array}$ & B & Wald & df & Sig. & $\operatorname{Exp}(B)$ \\
\hline PCI & .010 & 4.212 & 1 & .040 & 1.010 \\
\hline ITE & -.094 & 5.983 & 1 & .014 & .910 \\
\hline ID (1) & -.649 & 3.972 & 1 & .054 & .523 \\
\hline ITP & & 18.655 & 2 & .000 & \\
\hline ITP (1) & .262 & 18.460 & 1 & .000 & 1.300 \\
\hline ITP (2) & -.229 & 2.701 & 1 & .100 & .796 \\
\hline EM (1) & .947 & 6.153 & 1 & .012 & 2.578 \\
\hline EPATC (1) & .111 & 9.052 & 1 & .001 & 1.117 \\
\hline $\begin{array}{l}\operatorname{EM}(1)^{*} \\
\text { EPATC }(1)\end{array}$ & 1.711 & 13.172 & 1 & .000 & 5.535 \\
\hline Constant & .661 & .574 & 1.325 & 1 & .250 \\
\hline
\end{tabular}

$*$ Chi-square $=22.431($ Sig. $=.0$ 04), 2 Log likelihood $=123.716$, Cox \& Snell R Square $=.287$ and Nagelkerke R Square $=.321$.

Note: Where: $\mathrm{PCI}=$ Per capita income, ITE = Internal tourism expenditures, ID= Identity card (1= citizen), ITP $=$ Internal tourism trip purposes $(1=$ religious, $2=$ shopping and entertainment shopping and entertainment), EM= Effectiveness of media $(1=$ effective), EPATC $=$ Effectiveness of public authority for tourism campaigns $(1=$ effective $)$.

Source: Authors' calculation, 2019.

that than others tourisms purposes by $30 \%$. While the chances of internal tourism weighting for shopping and entertainment opportunities for other purposes of internal tourism weighting by about $20 \%$. The results show that religious purpose is highest in increasing the chances of weight domestic tourism compared to other purposes (shopping and entertainment, visiting relatives, treatment, study and work). By way of the role of the Saudi Tourism
Antiquities Authority in promoting and encourage the interior tourism, it is clear that whenever campaigns and festivals of Tourism Antiquities Authority are effective from the perspective of the respondent's vision, the greater the chances of tipping the domestic tourism in Saudi Arabia for foreign tourism twice and a half $(158 \%)$. Whereas the various Saudi medias play significant role in stimulating domestic tourism as the Saudi media 
were effective in promoting domestic tourism from the perspective of the respondent, the greater the likelihood ratio of domestic tourism in Saudi Arabia for foreign tourism by about $12 \%$. Whereas role of tourism and antiquities authority together with various media are effectively in promoting domestic tourism, the likelihood ratio of domestic tourism in Saudi Arabia for foreign tourism increases with around 624 .

\section{CONCLUSION AND FURTHER SUGGESTIONS}

The current article aims to detect the social and economic determinants of the likelihood of domestic tourism weighting on the foreign tourism, which will being considering in the formulating policies and in turn analyses the weight of domestic tourism to external tourism. The study depends on sectional data collected through questionnaires and depends on quantitative statistical analysis method using applied logistic regression model to identify the most important factors influencing the likelihood of domestic tourism in the KSA on foreign tourism. The most important obtained results reveal that increase the chances of internal tourism weighting on foreign tourism to Saudi citizen in compared with non-Saudi resident. Whereas the capita monthly, spending on domestic tourist trip, education, and the effectiveness of the role of the media is one of the most important factors that had increase the ratio of the weight of internal tourism opportunities in the KSA. The study address various suggestions and recommendation ensuring that the advised for further researches on tourism studies that are related to search of promoting and enhancing the role of know ledge and origination in tourism and embracing the vision 2030 in KSA. The study recommends to increase and improve quality of tourist services and give more attention for marketing purposes, recreational (sports, cultural, etc.) and focus on programs and diverse tourist patterns which targeting domestic tourism and local tourists as well as the stimulation of local tours.

\section{ACKNOWLEDGMENT}

The authors greatly extend thanks to Deanship of Scientific Research at King Faisal University, Al-Ahsa, Saudi Arabia for financial support under Nasher track grant number (186044).

\section{Conflict of Interest}

The authors declare no conflict of interest.

\section{REFERENCES}

Albaladejo I, González-Martínez M (2008). A Nonlinear Dynamic Model for International Tourism
Demand on the Spanish Mediterranean Coasts. 21(4), 65-78.

https://dx.doi.org/10.15240/tul/001/2018-4-005

Cafiso G, Cellini R, Cuccia T (2016). Do ec onomic crises lead tourists to closer destinations? Italy at the time of the Great Recession. Regional Science 97 (2), 369- 387. doi:10.1111/pirs. 12242

Castañeda J, Vena-Oya J, Rodríguez-Molina M, Martínez-Suárez R (2019). Analysis of domestic cultural tourism spend by segment in the city of Granada: An observational data approach. Tourism Management Perspectives 29, 18-30. Show more https://doi.org/10.1016/j.tmp.2018.10.001.

Chen C, Lin $Y$ (2019). The weather and macroeconomic determinants of whale-watching tourism: a Markov regime-switching analysis. Current Issues in Tourism. https://doi.org/10.1080/13683500.2017.1293620

Cheng-Fei L, King B (2019). Determinants of attractiveness for a seniors-friendly destination: a hierarchical approach. Current Issues in Tourism 22 (1),

90.https://doi.org/10.1080/13683500.2016.1250725

Filimonau V, De Coteau DA (2019). Food waste management in hospitality operations: A critical review. Tourism Management. 71, 234-245. https://doi.org/10.1016/j.tourman.2018.10.009

General Statically Authority (2018). Statistical Yearbook for the year 2017:53, Chapter 1: population and biological characteristics, Saudi Arabia.

General Statistical Authority (2018). Statistical Yearbook for the year 2017, Volume (53). Chapter 1: population and biological characteristics, Riyadh, Saudi Arabia. https://doi.org/10.1016/j.tourman.2013.04.005.

Gerdoci B, Skreli E, Zhllima E, Imami D (2017). Determinants of long-term business relationships in the dairy value chain in transition countries: the case of Albania. Studies in Agricultural Economics. 119, 139-147. https://doi.org/10.7896/j. 1709

Kesar O, Cuić K (2017). Shadow Economy in Tourism: Some Conceptual Considerations from Croatia. Zagreb International Review of Economics $\begin{array}{lll}\text { \& } & \text { Business. } & \text { 20(2): }\end{array}$ https://doi.org/10.1515/zireb-2017-0018

Kingdom of Saudi Arabia Vision 2030 (2017). Vision 2030. Kingdom of Saudi Arabia available at: https://vision2030.gov.sa/en

Kleinbaum DG, Klein M (2010). Logistic Regression A Self-Learning Text. Third Edition Springer New York Dordrecht Heidelberg London. DOI 10.1007/978-1-4419-1742-3. ISBN: 978-14419-1741-6

Lee Y, Chang WS (2016). Analyzing the effects of economic factors on modeling the diffusion of foreign exchange earnings from tourism in Taiwan. 
Abeer Abdalla Elsaid Kinawy et al., 2021

Tourism Economics. 22 (5), 1126-1131. https://doi.org/10.5367/te.2015.0466

Long-Yi L, Chen Y (2009). A study on the influence of purchase intentions on repurchase decisions: The moderating effects of reference groups and perceived risks. Tourism Review of AIEST - International Association of Scientific Experts in Tourism. 64 (3), 28-48. https://doi.org/10.1108/16605370910988818

Madaleno A, Eusébio C, Varum C (2019). Determinants of Visitors' Intentions to Consume and Recommend Local Agro-Food Products, Journal of Food Products Marketing. (25) 2, 159-186. https://doi.org/10.1080/10454446.2018.1501629

Manomaivibool $P$ (2015). Wasteful tourism in developing economy? A present situation and sustainable scenarios. Resources, Journal of Conservation and Recycling. 103 (1), 69-76. https://doi.org/10.1016/j.resconrec.2015.07.020

Ming M, Su Wall G, Wang Y, Jin M (2019). Livelihood sustainability in a rural tourism destination - Hetu Town, Anhui Province, China. Tourism Management. (71) 1, 272-281. https://doiorg.sdl.idm.oclc.org/10.1016/j.tourman.2018.10.019 Nikjoo AH, Ketabi M (2015). The role of push and pull factors in the way tourists choose their destination. Anatolia, an International Journal of Tourism and Hospitality Research. 26 (4), 588-597. https://doi.org/10.1080/13032917.2015.1041145

Pascariu GC, Ibănescu BC (2018). Determinants and Implications of the Tourism Multiplier Effect in EU Economies. Tow ards a Core-Periphery Pattern? Amfiteatru Economic. 20 (Special no. 12), 982-997. DOI: 10.24818/EA/2018/S12/982

Puah C, Huan S, Thien F (2018). Determinants of Chinese demand for tourism in Malaysia. Business

and Economic Horizons (BEH), Prague Development Center. 14 (3), 501-512. Handle: https://ideas.repec.org/a/pdc/jrnbeh/v14y2018i3p501 -512.html

Puah CH, Thien FT, Arip MA (2014). Singaporean demand for tourism in Malaysia. Economic Annals-XXI, 11-12, 32-36

Puri SC, Mullen K (1980). Applied Statistics for Food and Agricultural Scientists" Frist edition, g.k. hall medical publishers, Boston, U.S.A.

The world travel and Tourism Council (2018). Tourist information and Research Centre, 2018. "Summary of tourism 2016 (tourism), the Kingdom's most well received for tourists, Saudi Arabia. Website available (refer to the site on 5/2/1440). http://www.mas.gov.sa

Tourist information and Research Centre (2018). Summary of tourism 2016 (domestic tourism), the Kingdom's most well received for tourists, Saudi Arabia. Website available (refer to the site on 5/2/1440). http://www.mas.gov.sa

UNWTO (2018). 2017 Annual Report. (Accessed 24 Marth 2019). https://www.eunw to.org/doi/book/10.18111/9789284419807.

Yang CH, Lin HL, Han CC (2010). Analysis if international tourist arrivals in China: The role of w orld heritage sites. Tourism Management, 31, 827837.

Zdravko Šergo Z, Gržinić J (2018). Does The International Tourism Industry Relax Sovereign Credit Ratings: The Case Of Countries Most Reliant On Tourism. South East European Journal of Economics and Business. 13 (2), 100-111. DOI: https://doi.org/10.2478/jeb-2018-0014 


\title{
الملخص العربي
}

\author{
المحدات الاقتصادية والاجتماعية للسياحة الداخلية في المملكة العربية السعودية

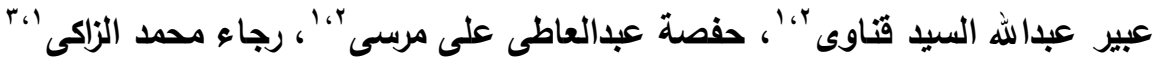 \\ 'كلية العلوم الزراعية والأغنية ،جامعة الملك فيصل بالإحساء \\ rكلية الزراعة جامعة عين شمس جمهورية مصر العربية

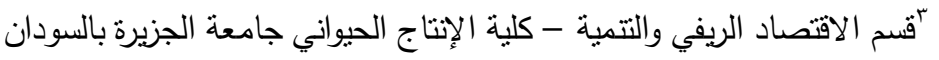

هدف الدراسة : نسعى الدراسة إلى تحديد أهم المحددات الاجتماعية والاقتصادية لترجيح السياحة الداخلية بالمملكة على السياحة

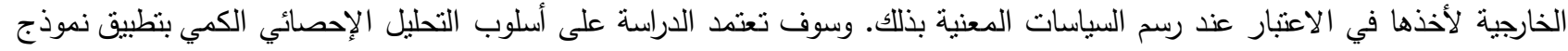
الانحدار اللوجستي التحديد أهم العوامل المؤثرة في ترجيح السياحة الداخلية بالمملكة على السياحة الخارجية نظراً لكون

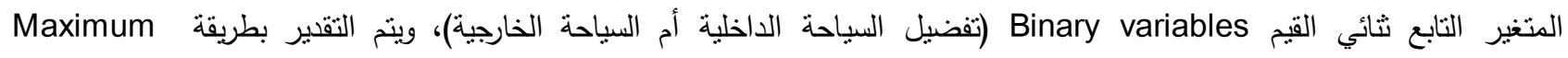
Likelihood للتغلب على المشاكل القياسية التي نتشأ حالة التقبير باستخدام الانحدار البسيط بطريقة Ordinary Least Square. فضلاً عن استخدام Dummy Variable للتمييز بين فعالية أو عدم فعالية بعض المحددات. وسوف تعتمد الدراسة على بيانات مقطعية يتم جمعها

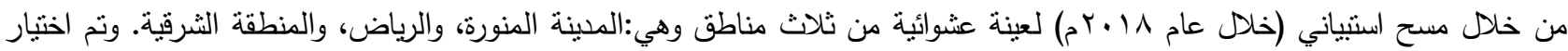

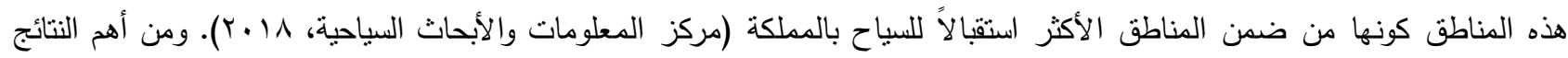

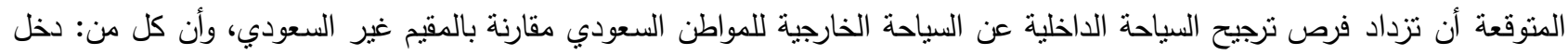
الفرد الثهري، وقيمة الإنفاق على الرحلة السياحية الداخلية، والتعليم، ومدى فعالية دور وسائل الإعلام تعد من أهم العوامل التي تزيد من نسبة ترجيح فرص السياحة الداخلية بالمملكة. الكلمات المفتاحية :السياحة المحلية ، العوامل الاجتماعية والاقتصادية ، السياحة الداخلية ، الإنفاق 